\title{
Peran Guru dalam Mengembangkan Bakat Siswa di Sekolah Dasar Negeri 34/I Teratai
}

\author{
Agung Rimba Kurniawan \\ Universitas Jambi \\ agung.rimba@unja.ac.id
}

Faizal Chan

Universitas Jambi

faizal.chan@unja.ac.id

Tania Juliani

Universitas Jambi

taniajuliani10@gmail.com

\section{Rosi Dwi Riski}

Universitas Jambi

rosidwi79@gmail.com

\section{Erni Ismaini}

Universitas Jambi

erniismaini0823@gmail.com

\author{
Agung Utomo \\ Universitas Jambi \\ agungutomo1234unja@gmail.com
}

\begin{abstract}
Talent (aptitude) is the potential of every individual brought from birth to be developed and trained in a sustainable manner. Every individual has different talents. Talent is closely related to knowledge competencies, attitudes and skills. The purpose of this study was to describe the role of the teacher in developing student talent in the Lotus Elementary School 34 / I. This study uses a qualitative approach to the type of phenomenological approach that is intended to describe a phenomenon experienced by the object of the researcher. The subjects in this study involved class teachers and students. Then, the research data were collected by observation and interview techniques, and supported by documentation. This research will prove that the teacher has an important role in developing the talents of individual students. The intended talent consists of academic talent and non-academic talent. Academic talent is talent related to the lessons in the classroom, while non-academic talent is talent skills outside the subject.
\end{abstract}

Keywords: The role of the teacher, students' talent

\begin{abstract}
Abstrak
Bakat (bakat) adalah potensi setiap individu yang dibawa sejak lahir untuk dikembangkan dan dilatih secara berkelanjutan. Setiap individu
\end{abstract}


memiliki bakat yang berbeda. Bakat terkait erat dengan kompetensi pengetahuan, sikap dan keterampilan. Tujuan dari penelitian ini adalah untuk menggambarkan peran guru dalam mengembangkan bakat siswa di Sekolah Dasar Lotus 34 / I. Penelitian ini menggunakan pendekatan kualitatif dengan jenis pendekatan fenomenologis yang dimaksudkan untuk menggambarkan suatu fenomena yang dialami oleh objek peneliti. Subjek dalam penelitian ini melibatkan guru kelas dan siswa. Kemudian, data penelitian dikumpulkan dengan teknik observasi dan wawancara, dan didukung oleh dokumentasi. Penelitian ini akan membuktikan bahwa guru memiliki peran penting dalam mengembangkan bakat individu siswa. Bakat yang dimaksud terdiri dari bakat akademis dan bakat non-akademik. Bakat akademik adalah bakat yang terkait dengan pelajaran di kelas, sedangkan bakat nonakademik adalah keterampilan bakat di luar mata pelajaran.

Kata kunci: Peran guru, bakat siswa

\section{Pendahuluan}

Bakat (aptitude) adalah suatu kemampuan khusus yang paling dominan pada diri seseorang (Rini, 2009:12). Senada dengan hal tersebut, (Muhammad, 2010:22) menyatakan bahwa bakat adalah suatu potensi pada diri seseorang yang perlu dilatih dan dikembangkan. Dimana kondisi seseorang tersebut membutuhkan latihan khusus guna mencapai suatu kecakapan, pengetahuan dan keterampilan khusus. Bakat yang dimiliki seorang anak berkaitan erat dengan lingkungan pendidikan. Dimana pendidikan merupakan salah satu tempat mengembangkan bakat siswa. Pendidikan merupakan suatu upaya untuk membentuk lingkungan bagi anak yang berguna merangsang perkembangan potensi-potensi dan bakat yang dimiliki siswa.

Bakat lahir dan tumbuh pada masa anak-anak dan remaja. Adapun proses perkembangan bakatnya dipengaruhi oleh pengalaman dan pola pikir di dalam lingkungan keluarga, sekolah maupun masyarakat sekitar (Sukardi, 2009:108). Bakat seorang anak perlu adanya dorongan dan dukungan. Apabila bakat itu dibiarkan tanpa ada dukungan, maka bakat yang dimiliki tidak berkembang secara maksimal. Bentuk dukungan tersebut diperoleh dari lingkungan sekitarnya, baik lingkungan keluarga, sekolah maupun pergaulannya. Karena nantinya karakter dan kepribadian anak akan mencerminkan bagaimana lingkungan disekitarnya. Peran bakat di era globalisasi ini sangtalah pentingan dan perlu dikembangkan. Dalam hal ini guru memiliki peran yang sangat besar dalam mengembangkan bakat siswa.

Guru memiliki peran sebagai sosok panutan yang memiliki nilai dan moral serta agama yang patut ditiru dan diteladani siswa sebagai contoh, keteladanan, budi pekerti luhur, akhlak mulia, jujur, tekun, mau belajar, amanah, sosial dan sopan santun terhadap sesama (Suparman, 2005:28). Dalam hal ini guru sangat berperan penting dalam pembentukan sikap siswa. Dengan cara, guru dapat memberikan berbagai macam bentuk contoh sikap yang baik terhadap siswa.

Selain peran diatas, guru juga memiliki peran lain yaitu sebagaimana yang dijelaskan oleh (Prey Katz pada Sardiman, 2001:143-144) yaitu Guru memiliki peran sebagai motivator dan pemberi inspirasi serta dorongan untuk mengembangkan sikap dan tingkah laku seseorang untuk menguasai suatu keterampilan. Dalam hal ini, guru harus mampu mengetahui dan mengembangkan bakat yang dimiliki oleh siswanya. 
Guru harus berusaha untuk mengetahui kebutuhan-kebutuhan yang menunjang pembelajaran siswa diantaranya adalah kewajiban untuk menyediakan informasi, bahan ajar, dan mengupayakan bagaimana cara memperoleh sumber-sumber belajar tersebut (Purwanti.E dan Widodo, 2002:12).

Senada dengan hal tersebut, penelitian ini didukung oleh penelitian relevan yang dilakukan oleh Wahyuni.S.A, Falah.N (2015) yang berjudul "Peran Guru Bimbingan Dan Konseling Dalam Mengembangkan Minat Dan Bakat Program Pilihan Studi Keterampilan Peserta Didik MAN 1 Magelang". Di MAN 1 Magelang ini selain menyediakan program jurusan umum yaitu IPA, IPS, Bahasa, dan Agama. Sekolah ini juga menyediakan program studi pilihan keterampilan peserta didik berbasis SMK, diprogram ini lah peserta didik mampu menyalurkan bakat dan minatnya serta mampu menentukan kemana arah peserta didik setelah lulus dari MAN 1 Magelang. Namun pada kenyataanya banyak sekali peserta didik yang belum mengenali minat dan bakatnya sendiri. Penelitian yang dilakukan Wahyuni.S.A, Falah.N merupakan penelitian kualitatif dengan tujuan untuk mengetahui peran guru bimbingan dan konseling dalam mengembangkan minat dan bakat program pilihan studi keterampilan peserta didik man 1 magelang. Penelitian ini menggunakan teknik pengumpulan data yaitu observasi dan wawancara. Hasil penelitian ini menunjukkan bahwa peran guru BK dalam mengembangkan minat dan bakat program studi pilihan keterampilan peserta didik MAN 1 Magelang yaitu sebagai taster, sebagai informasi, sebagai perencana program BK, sebagai adminitrator bimbingan, sebagai penasehat, dan sebagai konsultan.

\section{Metode}

Pendekatan yang dilakukan dalam penelitian ini yaitu pendekatan kualitatif. Penelitan ini akan mendeskripsikan bagaimana peran guru dalam mengembangkan bakat siswa di SD Negeri 34/1 Teratai. Jenis penelitian yang digunakan adalah fenomenologi, dengan melakukan penggalian data berupa bagaimana peran guru dalam megembangkan bakat siswa. Penggalian data ini diperoleh dengan teknik wawancara, observasi serta didukung dengan dokumentasi. Data diperoleh dari guru-guru kelas dan siswa-siswi di SD Negeri 34/1 Teratai. Teknik sampling yang digunakan dalam penelitian ini adalah purposive sampling.

Penelitian ini dilakukan dengan menggunakan prosedur sebagaimana mestinya. Proses awal yang dilakukan adalah tahap persiapan, dengan melakukan kegiatan menyusun instrumen penelitian, kemudian mendatangi informan. Setelah itu, kegiatan yang dilakukan adalah tahap pelaksanaan penelitian. Pada tahapan ini, terjadi proses pengumpulan data dengan menggunakan instrumen-instrumen yang sudah dipersiapkan, lalu data tersebut dikelola, dianalisis, dan disimpulkan. Proses terakhir pada prosedur penelitian ini adalah tahap penyelesaian. Pada tahapan ini kegiatan yang dilakukan yaitu menyusun data-data yang sudah diperoleh dan analisis dalam bentuk laporan hasil penelitian yang berbentuk deskripsi.

Dalam penelitian ini, sebagai informan penelitian yang ditentukan oleh peneliti adalah wali kelas di SD Negeri 34/1 Teratai. Alat yang digunakan dalam kegiatan penelitian ini disebut instrumen penelitian, dalam penelitian kualitatif, yang menjadi instrumen penelitian adalah peneliti itu sendiri. Guna menetapkan rumusan masalah, memilih informan sebagai sumber data, melakukan kegiatan pengumpulan data, menilai kualitas data, menganalisis data, serta membuat kesimpulan hasil penelitian.

Observasi merupaka teknik pengumpulan data dengan pengamatan yang diteliti secara sistematis melalui fenomena yang terjadi. Pengamaan dilakukan peneliti di SDN 34/I Teratai. Kegiatan pengamatan diambil dari perwakilan kelas I - VI. 
Kegiatan pengamatan ilakukan terhadap setiap guru kelas. Wawancara merupakan teknik pengumpulan data dengan cara tatap muka antara pihak penanya dan penjawab. Data dikumpulkan dengan cara untuk mendapakan informasi yang mendalam. Dalam penelitian ini menggunakan wawancara terstruktur, dengan serangkaian pertanyaan yang telah peneliti susun dalam bentuk pedoman wawancara dan untuk mengarahkan alur pembicaraan mengarah kepada tujuan hasil data yang diharapkan, serta penarikan kesimpulan. Teknik penguji keabsahan penelitian ini menggunakan triangulasi teknik. Dilakukan dengan cara mengecek data yang diperoleh melalui beberapa sumber sehingga menghasilkan kesimpulan.

Analisis data dalam penelitian ini menggunkan model Miles dan Hubeman yaitu meliputi reduksi data, penyajian data, serta penarikan kesimpulan atau verifikasi. Pada tahap reduksi data, yaitu semua hasil dari kegiatan penelitian kemudian diseleksi dan dibuat ringkasan. Pada tahap penyajian data, yaitu menyajikan data bahwa perlu pengecekan keabsahan untuk mengambil kesimpulan. Tahap penarikan kesimpulan dan verifikasi yaitu, peneliti membuat kesimpulan dan menganalisis data untuk mengetahui mengenai bakat siswa dan peran guru dalalm mengembangkannya.

\section{Hasil}

Hasil penelitian berupa deskripsi mengenai peran penting guru dalam mengembangkan bakat siswa. deskripsi tersebut berdasarkan observasi dan wawancara yang telah dilakukan untuk mengumpulkan data yang objektif. Berikut ini penjabarannya.

Tabel Transkip Wawancara

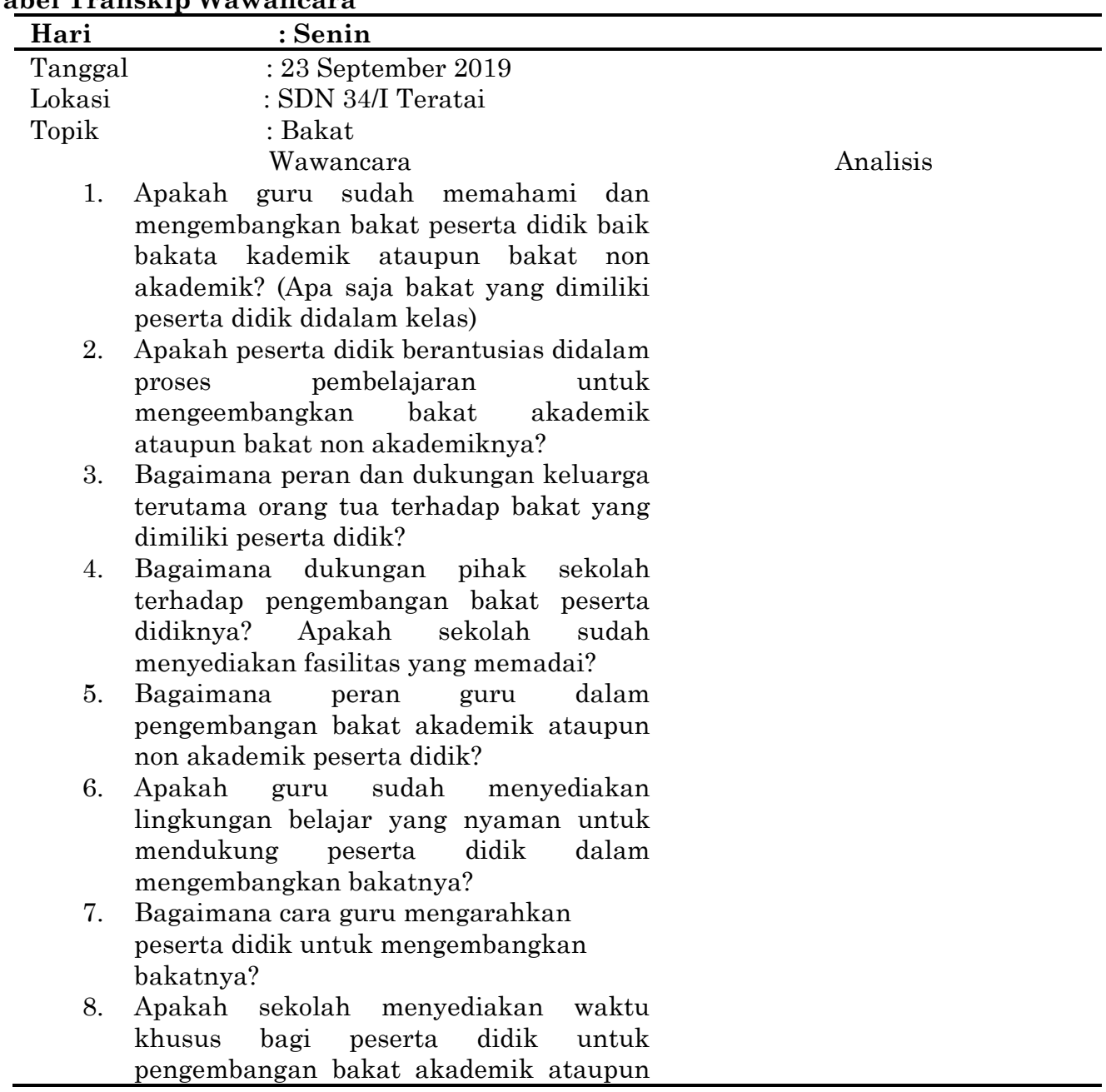


non akademik?

9. Bagaimana bentuk tanggapan dan dukungan masyarakat sekitar mengenai aktualisasi bakat yang dimiliki peserta didik?

10. Apakah ada fasilitas pendukung pengembangan bakat sebagai bentuk aktualisasi bakat peserta didik di masyarakat?

Hasil wawancara bersama wali kelas I yang bernama Erteti Waliyani, S.Pd.SD menyatakan bahwa guru masih berusaha untuk menumbuh kembangkan bakat yang muncul pada siswa baik di bidang akademik maupun non akademik. Pengembagan bakat dilakukan oleh guru di dalam proses pembelajaran dengan mengaitkan minat peserta didik sesuai dengan materi pembelajaran. Hal tersebut dilakukan untuk menghadirkan suasan pembelajaran yang nyaman bagi peserta didik sehingga akan muncul bibit minat dan kesukaan peserta didik pada suatu hal yang mengarah kepada bakat anak kedepan. Disnilah peran guru dirasa cukup berat karena selain membelajarkan peserta didik, guru juga berupaya menumbuhkan dan mengembaangkan bakat dan potensi peserta didik sejak dini.

Hasil wawancara bersama wali kelas II yang bernama Maimunah S.Pd menyampaikan bahwa pada diri peserta didik belum terlihat bakat yang dominan dikarenakan peserta didik masih ingin bermain dengan sesamanya didalam maupun diluar pembelajaran. Guru mencoba untuk mengenali bakat peserta didik dengan mengajak peserta didik aktif di dalam pembelajaran. Guru akan melihat ketertarikan peserta didik kepada hal-hal yang mereka sukai. Kemudian guru berupaya untuk membimbing agar bakat tersebut tumbuh dan berkembang dengan baik.

Hasil wawancara bersama wali kelas III yang bernama M. Sidiq S.Pd.SD menyampaikan bahwa guru sudah memahami dan mengembangkan bakat baik bakat akademik dan non akademik yang sudah mulai nampak pada peserta didik. Bakat yang sudah muncul diantaranya di bidang mata pelajaran IPA, MTK, IPS, Bahasa Indonesia yang dibuktikan dengan mengikuti Lomba Cerdas Cermat (LCC), selai itu bakat di bidang pramuka juga muncul pada diri peserta didik. Pengembangan bakat tersebut didukung oleh peran guru, orang tua dan masyarakat berupa fasilitas yang tersedia untuk menunjang bakat dan prestasi peserta didik.

Hasil wawancara bersama wali kelas IV yang bernama Yernelis, A.Ma, Pd menyampaikan bahwa guru sudah memahami dan mengembangkan bakat peserta didik baik di bidang akademik maupun non akademik, namun dalam penerapannya peserta didik kurang berantusias dalam proses pengembangan bakat di karenakan kurangnya peran dan dukungan orang tua serta kurang lengkapnya fasilitas yang di sediakan sekolah. selain itu guru juga merasa kesulitan di dalam penerapan pembelajaran tematik yang memadukan beberapa mata pelajaran dalam satu tema sehingga bakat peserta didik tidak muncul secara maksimal pada mata pelajaran tertentu.

Hasil wawancara bersama wali kelas V yang bernama Ani Prastiwi, S.Pd menyampaikan bahwa guru sudah memahami dan mengembangkan bakat peserta didik baik bakat kademik maupun non akademik, peserta didik juga sangat berantusias dalam mengembangkan bakatnya hal itu terlihat dari beberapa prestasi yang diraihnya seperti lomba membaca puisi dan cabang olahraga volley. Hal itu di dukung oleh peran guru dan dukungan keluarga terutama orang tua serta masyarakat. Selain itu sekolah menyediakan fasilitas yang cukup memadai dan 
memberikan waktu khusus untuk mengembangkan bakat peserta didik di hari sabtu.

Hasil wawancara bersama wali kelas VI yang bernaa Agustina, S.Pd.SD menyampaikan bahwa guru sudah memahami dan mengembangkan bakat peserta didik baik bakat akademik maupun non akademik yang sudah muncul dari kelas sebelumnya seperti di bidang bela diri dan agama. Peserta didik sangat berantusias di dalam proses pembelajaran untuk mengembangkan bakat. Hal itu di dukung oleh peran guru dan dukungan keluarga terutama orang tua serta masyarakat yang di buktikan dengan fasilitas yang di siapkan oleh sekolah dan orang tua, serta dukungan langsung yang diberikan orang tua di lapangan, namun pada kelas VI guru tidak memberikan waktu khusus untuk mengembangkan bakat siswa karena guru lebih memfokuskan peserta didik agar mempersiapkan diri untuk mengikuti Ujian Nasional.

\section{Pembahasan}

Data yang diperoleh dalam penelitian ini adalah data tentang peran guru dalam mengembangkan bakat siswa. Di SD N 34/1 Teratai sangat memperhatikan bakat dari siswanya. Dengan adanya pengembangan bakat inilah, siswa mampu mengetahui potensi dirinya baik itu kelebihannya maupun kekurangannya. Hal tersebut sesuai dengan penelitian relevan yang dilakukan oleh Yuianti, W (2016) yang mengatakan bahwa bakat merupakan sesuatu hal yang penting dalam jenjang pendidikan. Dengan adanya tes minat dan bakat, siswa dapat mengetahui potensi dirinya.

Berdasarkan hasil wawancara yang dilakukan guna memperoleh data-data valid berkaitan dengan peran guru terhadap perkembangan bakat siswa telah menunjukkan bahwa terdapat kontribusi yang banyak dalam perkembangan bakat siswa. peran guru dalam perkembangan bakat siswa di aplikasikan dalam bentuk penyampaian materi dalam pembelajaran secara formal (berkaitan materi pembelajaran), atau proses adopsi pengaitan pembelajaran diluar materi. Pemahaman guru terhadap minat dan bakat peserta didik perlu diwujudkan, selain untuk menciptakan pembelajaran yang nyaman tetapi juga meningkatkan motivasi dan prestasi belajar peserta didik. Pemahaman ini sejalan dengan Sardiman (2009:142) yang menyatakan bahwa guru harus mengenal siswanya, pengenalan ini ukan hanya sifat dan kebutuhannya secara umum sebagai sebuah kategori, minat dan kemampuan serta cara dan gaya mengajarnya tetapi guru harus memahami secara khusus dari sifat, bakat/pembawaan, minat, kebutuhan, pribadi serta aspirasi masing-masing anak didiknya.

Kegiatan pengembangan bakat siswa dilaksanakan melalui kegiatan pembelajaran dan didukung melalui kegiatan ekstrakulikuler. Sehingga proses pengembangan bakat dapat berjalan seiring dengan minat masing-masing siswa secara akademik ataupun non akademik. Guru memiliki peran untuk memberikan dorongan aktif pada setiap tahap dan proses pengembangan bakat yang difasilitasi dengan sarana dan prasaran sekolah. "Dorongan merupakan suatu pupuk yang menyuburkan bakat, serta mendewasakan siswa dalam meniti bakat serta kemampuannya" (Marhijanto, 2003:3). Salah satu dorongan untuk mengembangkan bakat di sekolah yaitu adanya kegiatan pengembangan diri . Dalam hal ini, SDN 34/I Teratai sudah mampu menyediakan fasilitas yang memadai secara kuantitas maupun kualitas. Sehingga dalam pengembangan bakat sangat dibantukan oleh adanya fasilitas tersebut. Selain itu, sekolah dan guru memberikan fasilitas dan waktu khusus untuk pengembangan bakat akadeik dan non akademik secara rutin diiringi pendampingan yang efektif. Impilkasinya adalah berbagai bentuk prestasi yang membanggakan berkaitan dengan bakat siswa tersebut. 


\section{Simpulan}

Berdasarkan penelitian yang telah di lakukan tentang peran guru dalam mengembangkan bakat siswa di SD Negeri 34/1 Teratai, dapat disimpulkan bahwa guru sudah mengembangkan bakat siswa di bidang akademik maupun di bidang non-akademik dengan baik, hal tersebut dapat terlihat dari keterlaksanaan indikator yang digunakan peneliti pada saat melakukan pengamatan secara langsung atau observasi serta didukung dengan hasil wawancara dan dokumentasi. Guru sudah melakukan berbagai macam peran dalam mengembangkan bakat siswa, seperti halnya guru sudah melakukan bimbingan dan memberikan waktu khusus terhadap pengembangan bakat siswa, memotivasi siswa dan selalu memberikan dorongan terhadap siswa untuk terus berlatih dan mengembangkan bakat yang dimiliki siswa baik di bidang akademik maupun non-akademik. Namun, intensitas bimbingan dan arahan bakat siswa disesuaikan dengan tingkat perkembangan siswa dan tingkat kebutuhan siswa. Di dalam pengembangan bakat, dibutuhkan kerjasama antara pihak sekolah didalamnya terlibat peran kepala sekolah, guru dan sarana prasarana sekolah kemudian peran orang tua dan masyarakat sekitar.

\section{Saran}

Berdasarkan hasil penelitian yang di lakukan, diharapkan bagi Sekolah penelitian ini dapat digunakan sebagai acuan dan perbandingan dalam mengembangkan bakat siswa. Bagi Guru penelitian ini dapat digunakan sebagai masukan dalam mengembangkan bakat siswa di Sekolah Dasar. Penelitian ini dapat di gunakan sebagai bahan untuk mengkaji ulang dengan menggunakan metodologi penelitian dan tempat penelitian yang berbeda. Serta dapat digunakan untuk melengkapi kekurangan dari penelitian ini agar dapat memperkaya perkembangan ilmu yang sudah ada. Selain itu untuk menambah pengetahuan serta wawasan dalam mengembangkan bakat siswa di Sekolah Dasar serta bisa di implementasikan untuk melaksanakannya dalam mengembangkan bakat siswa baik di bidang akademik maupun non-akademik.

\section{Referensi}

Akbar, R, Hawadi. 2001.Psikologi Perkembangan Anak Mengenai Sifat, Bakat Dan Kemampuan Anak. Jakarta: Grasindo.

Asmini, J., M. 2012 .Kiat Mengembangkan Bakat Anan Di Sekolah. Yogyakarta : Diva Press.

Dalyono. 2010. Psikologi Pendidikan. Jakarta : Rineka Cipta.

Darmadi, H. 2010. Kemampuan Dasar Mengajar. Bandung, Alfabeta,

Hamzah, M., K. 2009.Mengelola Kecerdasan Dalam Pembelajaran. Jakarta : PT Bumi Aksara.

Mulyana, D. 2008.Metodologi Penelitian Kualitatif. Bandung : PT Rosdakarya.

Sardiman. 2009.Interaksi Dan Motivasi Belajar Mengajar. Jakarta: Raja Grafindo Persada.

Sukardi, dkk. 2009.Tes Psikologi. Jakarta: Rhineka Cipta. 
Sugiyono. 2013. Metode Penelitian Kuantitatif, Kualitatif Dan $R \& D$. Bandung : CV Alfabeta.

Yulianti, W. 2016. Aptitude Testing Berbasis Case-Based Reasoning dalam Sistem Pakar untuk Menentukan Minat dan Bakat Siswa Sekolah Dasar. J. Teknol. Dan Sist. Inf. Univrab, 1(2). 104-118.

Yusuf, dkk. 2011. Perkembangan Peserta Didik. Jakarta : PT Raja Grafindo Persada. 